\title{
Lama Penyimpanan Air Susu Ibu (ASI) Memengaruhi Kandungan Zat Gizi Dalam ASI
}

\author{
Sri Handayani, Dian Soekmawaty Riezqy Ariendha, Yopi Suryatim Pratiwi \\ Email : Srihandayani@stikesyarsimataram.ac.id \\ Prodi Kebidanan Jenjang D.3 STIKes Yarsi Mataram
}

\begin{abstract}
ABSTRAK
Kondisi dimana ibu bekerja merupakan salah satu kondisi yang menghambat pemberian ASI. Agar wanita bekerja tetap dapat memberikan ASI maka diperlukan pemerahan dan penyimpanan ASI. Proses penyimpanan dapat mengawetkan ASI hingga beberapa waktu. Adanya perlakuan lama penyimpanan ASI diduga dapat menyebabkan perubahan-perubahan fisik maupun komposisi kimia. Berdasarkan beberapa hasil penelitian dapat disimpulkan lama penyimpanan ASI baik dalam lemari es maupun freezer akan memengaruhi jumlah kadar lemak dan protein dalam ASI. Penyebab kerusakan lemak dibedakan atas tiga golongan, yaitu kerusakan karena oksidasi, adanya enzim, dan reaksi hidrolisis lemak. Perubahan kadar protein ASI selama penyimpanan, kemungkinan bisa disebabkan terjadinya proses proteolisis dan denaturasi protein.
\end{abstract}

Kata kunci: Penyimpanan ASI, Zat Gizi

\begin{abstract}
The condition in which the mother works is one of the conditions that inhibits breastfeeding. In order for women to work, they can still provide breast milk, so milking and storage are needed. The storage process can preserve breast milk for some time. The existence of a long treatment of breast milk storage is suspected to cause physical changes and chemical composition. Based on several research results, it can be concluded that the duration of breast milk storage both in the refrigerator and freezer will affect the amount of fat and protein content in breast milk. The cause of fat damage is divided into three groups, namely damage due to oxidation, the presence of enzymes, and fat hydrolysis reaction. Changes in protein levels of breast milk during storage may be caused by the process of proteolysis and protein denaturation.
\end{abstract}

Keywords: Storage of breast milk, Nutrition

\section{A. LATAR BELAKANG}

ASI adalah makanan alami, dapat diperbaharui, berfungsi sebagai sumber gizi lengkap bagi bayi selama enam bulan pertama kehidupan. ASI adalah makanan terbaik bayi dan memiliki keseimbangan nutrisi yang tepat, tersedia secara biologis, mudah dicerna, melindungi baik ibu dan anak dari penyakit, dan memiliki sifat anti-inflamasi.[1] ASI merupakan cairan komplek yang terdiri dari berbagai komponen kimia dan seluler.[2] ASI adalah satu jenis makanan yang mencukupi seluruh unsur kebutuhan bayi, baik fisik, psikologi, sosial, dan spiritual.[3]
Survey Demografi Kesehatan Indonesia (SDKI) tahun 2017 menunjukkan bahwa Lebih dari separuh (53\%) wanita kawin umur 15-49 bekerja. wanita yang bekerja meningkat sejalan dengan makin tingginya umur. Persentase wanita yang bekerja pada umur 15-19 adalah 23 persen, sedangkan untuk umur 45- 49 tahun sebesar 68 persen. Lima puluh lima persen wanita di perkotaan dan 52 persen wanita di perdesaan berstatus bekerja.[4]

Kondisi dimana ibu bekerja merupakan salah satu kondisi yang menghambat pemberian ASI. Agar wanita bekerja tetap dapat memberikan ASI maka diperlukan pemerahan 
dan penyimpanan ASI pada lemari es atau freezer. Proses penyimpanan dapat mengawetkan ASI hingga beberapa waktu. Pengawetan bertujuan untuk mempertahankan kualitas bahan makanan. Kualitas bahan makanan sendiri dapat dilihat dari kualitas gizinya. Adanya perlakuan lama penyimpanan air susu ibu (ASI) diduga dapat menyebabkan perubahan-perubahan fisik maupun komposisi kimia. Dengan adanya perubahan kimiawi tersebut maka kemungkinan besar akan terjadi kerusakan zat gizi pada ASI.[5]

\section{B. METODE PENELITIAN}

Studi ini merupakan suatu tinjauan literatur (literature review) yang mencoba menggali lama penyimpanan ASI terhadap kandungan zat gizi dalam ASI. Sumber untuk melakukan tinjauan literatur ini meliputi studi pencarian sistematis data base terkomputerisasi (Pubmed, Pro Quest, dan google cendekia) bentuk jurnal penelitian. Penulisan artikel ini menggunakan penulisan daftar pustaka Harvard.

\section{HASIL DAN PEMBAHASAN \\ 1. Hasil Penelitian}

Beberapa penelitian menunjukkan lama penyimpanan ASI akan memengaruhi kandungan zat gizi dalam ASI. Hal tersebut dapat dilihat pada tabel 1 berikut.

\section{Pembahasan}

ASI mengandung semua zat yang dibutuhkan oleh bayi pada enam bulan pertama kehidupan, termasuk lemak, karbohidrat, protein, vitamin, mineral, dan air. Makronutrien utama dalam ASI adalah laktosa dan oligosakarida [2]. ASI mudah dicerna dan efisien dalam penggunaan. ASI juga mengandung faktor bioaktif yang meningkatkan sistem kekebalan tubuh bayi yang belum matang, menyediakan perlindungan terhadap infeksi, dan faktor-faktor lain yang membantu pencernaan dan penyerapan nutrisi.

Komposisi makronutrien pada ASI matur bayi aterm dalam $100 \mathrm{ml}$ ASI adalah protein 0,9-1.2 g/dL, lemak 3,2-3,6 g/dL, dan laktosa
$7,8 \mathrm{~g} / \mathrm{dL}$. Perkiraan energi berkisar $65-70$ $\mathrm{kkal} / \mathrm{dL}$ dan sangat berkorelasi dengan kandungan lemak ASI. Komposisi makronutrien berbeda antara bayi prematur dan aterm. ASI pada bayi prematur mengandung protein yang lebih tinggi dibandingkan lemak.[9] Perbedaan hingga $35 \%(0,7 \mathrm{~g} / \mathrm{dL})$ dalam kolostrum, namun setelah 3 hari postpartum perbedaan menjadi 0,2 g/dL. Pada 10-12 hari pospartum, susu aterm sama seperti susu prematur.[10]

Berdasarkan hasil penelitian (tabel 1) terdapat perubahan kadar lemak dan protein pada ASI baik yang disimpan pada lemari pendingin maupun freezer.

\section{Kadar Lemak}

Lemak adalah makronutrien yang paling bervariasi dan menyediakan sekitar satu setengah dari kandungan energi susu. Lemak ASI ditandai dengan tingginya asam palmitat dan oleat. Lemak disekresikan dalam tetesan kecil dan jumlah yang meningkat selama berlangsungnya proses menyusui. Akibatnya, hindmilk yang dikeluarkan menjelang akhir menyusui kaya lemak, yaitu mengandung dua sampai tiga kali konsentrasi lemak ASI yang terdapat pada foremilk dan terlihat berwarna putih krem. Foremilk dikeluarkan pada awal menyusui, mengandung sedikit lemak, dan terlihat berwarna agak abu-abu kebiruan.[11,12] Peningkatan kadar lemak susu terutama hasil dari peningkatan jumlah Milk Fat Globules (MFGs).[13] Lemak ASI mengandung asam lemak tak jenuh ganda rantai panjang (docosahexaenoic acid atau DHA, dan asam arakidonat atau ARA) yang tidak tersedia pada susu lainnya. Asam lemak penting untuk perkembangan saraf seorang anak.[12]

Penyebab kerusakan lemak dibedakan atas tiga golongan, yaitu kerusakan karena oksidasi, adanya enzim, dan reaksi hidrolisis lemak. Kerusakan lemak dapat disebabkan oleh proses oksidasi terhadap asam lemak tidak jenuh. Kecepatan oksidasi berbanding lurus dengan tingkat ketidakjenuhan asam lemak, semakin tidak jenuh suatu asam lemak, maka akan semakin mudah teroksidasi. Kecepatan proses 
Tabel 1. Hasil Penelitian dari Tinjauan Literatur

\begin{tabular}{|c|c|c|c|}
\hline No & Penulis & Metode & Hasil Penelitian \\
\hline 1. & $\begin{array}{ll}\text { Griennasty } & \text { Clawdya } \\
\text { Siahaya, Bellytra } \\
\text { Talarima }\end{array}$ & $\begin{array}{l}\text { Penelitian ini menggunakan } \\
\text { Rancangan Acak Lengkap } \\
\text { (RAL) dengan } 4 \text { perlakuan dan } 3 \\
\text { kali ulangan. Perlakuannya } \\
\text { meliputi penyimpanan ASI } \\
\text { perah pada suhu }-15^{\circ} \mathrm{C} \text { dengan } \\
\text { lama waktu penyimpanan } 0 \text { (nol) } \\
\text { hari, } 4 \text { hari, } 8 \text { hari, dan } 12 \text { hari }\end{array}$ & $\begin{array}{l}\text { Hasil penelitian menunjukkanlama } \text { waktu } \\
\text { penyimpanan ASI pada suhu }-15^{\circ} \mathrm{C} \\
\text { berpengaruh nyata terhadap kadar protein, } \\
\text { terjadi peningkatan kadar protein dalam jumlah } \\
\text { yang kecil pada penyimpanan hari ke- } 4 \text { hingga } \\
\text { penyimpanan hari ke- } 8 \text { dan di hari ke-12 terjadi } \\
\text { penurunan kadar protein.[6] }\end{array}$ \\
\hline 2. & $\begin{array}{l}\text { Indri Putri Sari, } \\
\text { Ariadi, Ety Yerizel }\end{array}$ & $\begin{array}{l}\text { Metode yang digunakan dalam } \\
\text { penelitian ini adalah true } \\
\text { experiment dengan pendekatan } \\
\text { pretest-post test control group } \\
\text { design. }\end{array}$ & $\begin{array}{l}\text { Hasil penelitian didapatkan terdapat efek lama } \\
\text { penyimpanan ASI terhadap kadar protein dan } \\
\text { lemak yang terkandung di dalam ASI. kadar } \\
\text { protein yang disimpan dalam lemari pendingin } \\
\text { mengalami penurunan, yaitu selama } 0 \text { jam } \\
\text { adalah } 0,99 \%, 24 \text { jam } 0,86 \%, 48 \text { jam } 0,78 \%, 72 \\
\text { jam } 0,72 \% \text {. Rerata untuk kadar lemak juga } \\
\text { mengalami penurunan selama penyimpanan } 0 \\
\text { jam adalah } 3,4 \%, 24 \text { jam } 3,2 \%, 48 \text { jam } 3,1 \% \\
\text { dan } 72 \text { jam } 3,0 \% \text {. [7] }\end{array}$ \\
\hline 3. & $\begin{array}{l}\text { Nadia Raquel } \\
\text { Garcı'a-Lara, Diana } \\
\text { Escuder-Vieco, } \\
\text { Oscar Garcı'a- } \\
\text { Algar, } \\
\text { Javier De la Cruz, } \\
\text { David Lora4 and } \\
\text { Carmen Palla' s- } \\
\text { Alonso }\end{array}$ & $\begin{array}{l}\text { Penelitian dilakukan dengan } \\
\text { mengumpulkan ASI di dalam } \\
\text { lemari pendingin. Sampel dicek } \\
\text { pada } 0 \text { hari, hari ke-7, ke-15, ke- } \\
\text { 30, ke-60, dan hari ke-90. }\end{array}$ & $\begin{array}{l}\text { Hasil penelitian menunjukkan setelah ASI di } \\
\text { simpan lebih dari } 3 \text { bulan pada freezer dengan } \\
\text { suhu }-20^{\circ} \mathrm{C} \text { didapatkan penurunan jumlah kadar } \\
\text { lemak dan kalori dalam ASI.[8] }\end{array}$ \\
\hline 4. & $\begin{array}{l}\text { Titin Aryani, Fitria } \\
\text { Siswi Utami, } \\
\text { Sulistyaningsih, } \\
\text { Ulfa Mu'awanah, } \\
\text { Isnin Aulia }\end{array}$ & $\begin{array}{l}\text { Penelitian ini merupakan } \\
\text { penelitian kuantitatif dengan } \\
\text { rancangan kuasi eksperimen. }\end{array}$ & 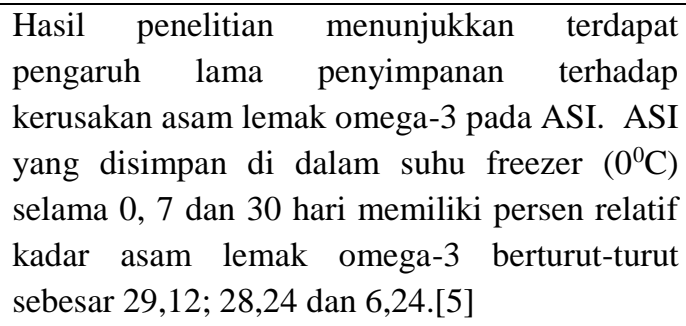 \\
\hline
\end{tabular}

oksidasi juga tergantung dari tipe lemak dan kondisi penyimpanan. Asam lemak omega-3 merupakan asam lemak yang sangat tidak jenuh sehingga dapat mengalami reaksi oksidasi asam lemak dengan lebih mudah dibandingkan asam lemak lainnya yang terdapat dalam ASI.[14]

Penyimpanan ASI yang lebih lama memungkinkan sampel ASI terpapar oksigen lebih banyak melalui celah botol sampel. Tekanan oksigen yang meningkat pada lama penyimpanan yang lebih lama menyebabkan laju oksidasi asam lemak omgega-3 pada sampel ASI meningkat. Dengan meningkatnya laju oksidasi maka kadar asam lemak omega-3 pada sampel ASI yang disimpan lebih lama menjadi lebih kecil atau menurun bila dibandingkan kadar asam lemak omega-3 pada sampel ASI yang disimpan lebih cepat.[5]

Perubahan kadar lemak selama penyimpanan disebabkan ASI bisa mengalami lipolisis. Lipolisis adalah proses hidrolisis ikatan ester pada lemak (triacylglycerols) sehingga menghasilkan asam lemak bebas dan gliserol.[15] Enzim lipase yang dihasilkan dari metabolisme Bakteri Asam Laktat (BAL), maupun yang terdapat secara alami dalam susu, 
serta sifat lipolitik yang dimilikinya menghidrolisis lemak, sehingga menghasilkan asam lemak bebas dan gliserol. Enzim lipase tersebut berasal dari mikroba atau terdapat secara alami di dalam susu.[7]

Aktivitas bakteri lipolitik yang menghasilkan enzim lipase didalam ASI. Bakteri lipolitik ini sendiri merupakan bakteri yang membutuhkan konsentrasi lemak minimal tertentu untuk pertumbuhannya. Enzim lipase yang dihasilkannya memecah lemak menjadi asam lemak dan gliserol. Sehingga kadar lemak yang terkandung didalam ASI menjadi berkurang.[16]

ASI mengandung Mikroba dan jamur tersebut mengeluarkan enzim yang dapat menguraikan trigliserida lemak menjadi asam lemak bebas dan gliserol. Dengan meningkatnya kuantitas gliserol dan asam lemak bebas yang dihasilkan maka kadar asam lemak omega-3 semakin menurun/rusak. Dengan demikian semakin lama penyimpanan kadar asam lemak omega-3 pada sampel air susu ibu tersebut akan menurun.[5]

\section{Kadar Protein}

Protein ASI berbeda dari segi kuantitas dan kualitas dibandingkan susu hewan dan mengandung keseimbangan asam amino yang membuat ASI jauh lebih cocok untuk bayi. Protein dalam ASI dibagi menjadi fraksi whey dan kasein. Masing-masing terdiri atas protein spesifik dan peptida. Protein yang paling banyak adalah kasein, $\alpha$-lactalbumin, laktoferin, sekretori imunoglobulin A ( $\operatorname{sg} \mathrm{A})$, lisozim, dan serum albumin. Senyawa non-protein yang mengandung nitrogen, termasuk urea, asam urat, kreatin, kreatinin, asam amino, dan nukleotida, terdiri atas $25 \%$ dari nitrogen ASI. Kandungan protein susu yang diperoleh dari ibu yang melahirkan bayi prematur secara signifikan lebih tinggi dari ibu yang melahirkan bayi aterm.[9] Konsentrasi protein tidak dipengaruhi oleh diet ibu, tetapi dipengaruhi oleh berat badan ibu terhadap tinggi badan dan penurunan jumlah produksi ASI yang lebih tinggi.[17]
Perubahan kadar protein ASI selama penyimpanan, kemungkinan bisa disebabkan terjadinya proses proteolisis selama dalam masa penyimpanan. Proses proteolisis ini menjadi substansi/unsur yang dimanfaatkan oleh bakteri misalnya sebagai energi. Mekanisme perubahan tersebut biasanya akan menghasilkan air dan secara otomatis konsentrasi protein semakin menurun.[7]

Perubahan kadar protein juga bisa disebabkan kondisi ekstrim yang diartikan sebagai perubahan struktur sekunder, tersier dan kuartener terhadap molekul protein. Protein yang terdenaturasi akan berkurang kelarutannya. Denaturasi protein ini sendiri bisa terjadi karena beberapa faktor, seperti panas, asam basa, bahan kimia dan sebagainya.[18]

\section{KESIMPULAN}

Berdasarkan beberapa hasil penelitian dapat disimpulkan lama penyimpanan ASI baik dalam lemari es maupun freezer akan memengaruhi jumlah kadar lemak dan protein dalam ASI. Penyebab kerusakan lemak dibedakan atas tiga golongan, yaitu kerusakan karena oksidasi, adanya enzim, dan reaksi hidrolisis lemak. Perubahan kadar protein ASI selama penyimpanan, kemungkinan bisa disebabkan terjadinya proses proteolisis dan denaturasi protein.

\section{E. UCAPAN TERIMA KASIH}

Terima kasih kami ucapkan kepada rekan-rekan dosen Prodi Kebidanan Jenjang D.3 STIKes Yarsi Mataram yang telah memberikan dukungan sehingga artikel ini dapat terselesaikan dengan baik.

\section{DAFTAR PUSTAKA}

[1] Mekuria G, Edris M. Exclusive breastfeeding and associated factors among mothers in Debre Markos, Northwest Ethiopia: a cross-sectional study. International breastfeeding journal. 2015;10(1):1-7. 
[2] Schanler RJ, Potak DC. Physiology of lactation. 2014.

[3] Rondonuwu V, Loho M, Suparman E. Tingkat Pengetahuan Ibu Menyusui tentang Pemberian Asi Eksklusif di Bagian Obstetri Dan Ginekologi BLU RSU Prof. Dr. Rd Kandou Manado. eCliniC. 2014;2(2).

[4] Kementerian Kesehatan RI. Survei Demografi dan Kesehatan Indonesia (SDKI) 2017. Jakarta: Badan Penelitian dan Pengembangan Kesehatan Kementerian RI. 2017.

[5] Aryani T, Utami FS, Ulfah IA. Pengaruh Lama Penyimpanan Terhadap Kerusakan Asam Lemak Omega-3 Pada Air Susu Ibu (ASI). KESMAS, Vol.10, No.2, September 2016, pp. 169-176.

[6] Siahaya GC, Talarima B. Pengaruh Lama Penyimpanan Air Susu Ibu (ASI) pada Suhu $-15^{\circ} \mathrm{C}$ Terhadap Kualitas ASI. 2TRIK: Tunas-Tunas Riset Kesehatan Volume VII Nomor 1, Februari 2017

[7] Sari IP, Ariadi, Yerizel E. Efek Lama Penyimpanan Asi Terhadap Kadar Protein dan Lemak yang Terkandung Didalam ASI. Jurnal Kesehatan Andalas. 2016; 5(1).

[8] Garci'a-Lara NR, Escuder-Vieco D, Garc1'a-Algar O, Cruz JD, Lora D, Palla' s-Alonso C. Effect of Freezing Time on Macronutrients and energy Content of Breastmilk. Breastfeeding MedicineVolume 7, Number 4, 2012

[9] Ballard O, Morrow AL. Human milk composition: nutrients and bioactive factors. Pediatric Clinics of North America. 2013;60(1):49-74.
[10] Gidrewicz DA, Fenton TR. A systematic review and meta-analysis of the nutrient content of preterm and term breast milk. BMC pediatrics. 2014;14(1):216.

[11] Saarela T, Kokkonen J, Koivisto M. Macronutrient and energy contents of human milk fractions during the first six months of lactation. Acta Paediatrica. 2005;94(9):1176-81.

[12] Leake RD, Waters CB, Rubin RT, Buster JE, Fisher DA. Oxytocin and prolactin responses in long-term breast-feeding. Obstetrics and gynecology. 1983;62(5):565-8.

[13] Mizuno K, Nishida Y, Taki M, Murase M, Mukai Y, Itabashi K, et al. Is increased fat content of hindmilk due to the size or the number of milk fat globules. Int Breastfeed J. 2009;4(1):7.

[14] Ketaren, S. 1986. Pengantar Teknologi Minyak dan Lemak Pangan. Cetakan Pertama. Jakarta : UI-Press. Mangoensoekarjo, S. 2003.

[15] Rahman MS. Handbook of food preservation. Edisi ke-2. Boca Raton: CRC Press; 2007. hlm.1224-9.

[16] Ronzio R. The encyclopedia of nutrition and good health. Edisi ke-2. New York: Fact of File inc; 2003.

[17] Nommsen LA, Lovelady CA, Heinig MJ, Lönnerdal B, Dewey KG. Determinants of energy, protein, lipid, and lactose concentrations in human milk during the first 12 mo of lactation: the Darling Study. The American journal of clinical nutrition. 1991;53(2):457-65.

[18] Widyani R,Suciati T. Prinsip Pengawetan pangan Cirebon: Swagati Press; 2008. 